\title{
Enhancing the performance of students in chemistry through flipped classroom with peer instruction teaching strategy
}

\author{
Aprhodite Macale, Marivic Lacsamana, Maria Ana Quimbo and Edmund Centeno \\ University of the Philippines, Philippines
}

\begin{abstract}
This study examines the implementation of flipped classroom with peer instruction teaching strategy to Grade 7 public high school students in Laguna, Philippines. To analyze the effect of flipped classroom with peer instruction on Chemistry achievement, a two-group quasi-experimental pretest-posttest research design was used. In addition, student perception and participation were conducted using a post-implementation survey. In the flipped classroom with peer instruction, the students were introduced to the lesson using the science courseware developed by the Department of Science and Technology and YouTube videos as pre-class activities. The in-class activity was focused on answering concept questions through peer instruction. Findings show that the two groups of students significantly increased their Chemistry achievement after the implementation of the teaching strategies. However, the students in the flipped classroom with peer instruction had higher Chemistry achievement, high level of participation, and wide acceptance of the teaching strategy than the control group. With this teaching strategy, the students were able to complete their assigned tasks on time, show cooperative and supportive attitude during classroom discussion and activities, share ideas in class, and show respect for the opinion of others. On the contrary, students in the traditional classroom with peer instruction setup performed poorly on these aspects of classroom participation.
\end{abstract}

ARTICLE DETAILS
LUMAT General Issue
Vol 9 No 1 (2021), 717-747
Received 21 May 2021
Accepted 14 September 2021
Published 22 September 2021
Pages: 31
References: 45
Correspondence:
ammacale@up.edu.ph
https://doi.org/10.31129/
LUMAT.9.1.1598

Keywords: Flipped classroom, peer instruction, science courseware

\section{Introduction}

Engaging students in the learning process has always been a challenge for teachers. With the students' increased access to technology such as computers, gadgets, and the Internet, many teachers have recognized the potential of these tools in facilitating their classes (Ifenthaler et al., 2018). One strategy that highlights technology integration in teaching and that has become popular nowadays in the Philippines is blended learning (Custodio, 2020).

The flipped classroom, a blended learning approach, is a model of teaching where students get exposure to instructional content using readings, videos, or other learning resources outside the class. Students perform pre-class activities asynchronously. This approach allows the teacher and the students to do active 
learning activities inside the classroom. More importantly, students get immediate support and feedback from the teacher and fellow students (Srinivasan et al., 2018). Some active learning strategies employed in flipped classrooms include problembased learning, simulation, debates, and think-pair-share (Gilboy et al., 2014), knowledge sharing, contests, brainstorming, group discussions, practical work, and presentations (Shih and Tsai, 2017), among others. In the Philippines, teachers use active learning activities such as group workshops, worksheets, engage and explore activities, and exercises and problem sets (Camiling, 2017; Gayeta, 2017; Malto et al., 2018).

Research studies on flipped classroom showed that many teachers were satisfied and would recommend this teaching modality. They also observed improvement in academic achievement (Goodwin \& Miller, 2013; Rivero, 2013). For instance, studies conducted on the effects of flipped classroom in the Philippines showed a significant increase in student performance in biology (Malto et al., 2018), physics (Cagande and Jugar, 2018), and trigonometry (Calamlam, 2016; Segumpan and Tan, 2018). In addition, the flipped classroom revealed positive effects in different grade levels starting with science process skills for elementary, junior high school, and college students (Camiling, 2017).

The flipped classroom teaching strategy used in this study integrates peer instruction as a form of active learning activity in teaching Chemistry for Grade 7 students. Peer instruction, developed by Eric Mazur in Harvard University, is an active learning activity which centers on collaborative work (Chou and Lin, 2015). The discussion is initiated with a question which requires application of previously acquired knowledge on a principle in a specific course content. During peer instruction, the teacher monitors and corrects any misconception or issues. With the structure of peer instruction, students acquire more problem-solving skills than what they can develop alone (Morice et al., 2015). Peer instruction keeps even the passive students engaged and see multiple approaches to problems, increases comprehension, and creates a lively classroom atmosphere (Lucas, 2009; Morice et al., 2015). According to Crouch et al. (2007), peer instruction provides immediate feedback to students. In this strategy, the teachers became more satisfied with the increased engagement of the students in class. Students were found to be more satisfied with the course delivery and had higher retention in courses taught using peer instruction. 


\section{Theoretical and conceptual frameworks}

The theoretical framework of this study lies in the context of not using classroom time for lectures. Jean Piaget's theory of learning focused on student-centered teaching (Piaget, 2008). He pointed out that learning progresses as a factor of student's inherent capabilities and of the learning environments where he acquires new information and skills. Environmental factors include the role of the teacher and how actively engaged a student is in the classroom. As implied in Piaget's theory, the classroom should be a place for active learning where the teacher is the facilitator. Moreover, learners can reconstruct "truth" with other learners. Following the constructivist theory of learning, teachers should not simply lecture. Instead, teachers should encourage them to work in groups to think about issues and questions which facilitate cognitive growth and learning.

Learning with peers is also advocated by Lev Vygotsky in his social learning theory. According to his theory, important learning occurs when a student interacts and discusses with peers and/or tutors (Berk \& Winsler, 1995). Flipped classroom with peer instruction spurred from Vygotsky's zone of proximal development. Vygotsky (1978) defines the zone of proximal development as "the distance between the actual developmental level as determined by independent problem solving and the level of potential development as determined through problem solving under adult guidance, or in collaboration with more capable peers". Students interacting with competent peers effectively develop competencies and skills. Students learn from the explanation and approach of the more competent peer; in return, the more competent peer also learns as he applies the concept to different situations.

In addition, this new learning model is also anchored on the key findings of the National Research Council's article on "How People Learn?" (Bransford et al., 2000):

1. A deep understanding of factual knowledge, skill in contextualizing facts and ideas and organizing them for retrieval and application is necessary for students to develop competence in an area.

2. Students who were taught using metacognitive approach are more likely to develop autonomy in learning. They define their learning goals and monitor their progress related to the set goals. Thru peer instruction, students can monitor their own understanding. This activity will lead to adaptive expertise (Baroody, 2003). 
The learning theories and information on recent technological advancements serve as anchors for the implementation of flipped classroom with peer instruction.

The schematic diagram of the conceptual framework for this study is shown in Figure 1. This study is founded on the assumption that when students come to class equally prepared, they can participate and be more engaged in class. In effect, teachers can better aim for higher level of intended learning goals. Figure 1 shows how the flipped classroom with peer instruction requires individual/independent learning before class and interaction with teacher and peers during class. The pre-class activities using the Department of Science and Technology (DOST) science courseware and YouTube videos prepare students for active engagement in class. Since students learn at different paces, it is expected that some students will learn and grasp lessons ahead of others. This results in an increase in the gap between what should be taught, what is actually taught, and what the students learn in the lesson. In the flipped classroom with peer instruction approach, students learn and understand the lesson outside the classroom. Class hours will be devoted to higher levels of cognition as the students apply, analyze, evaluate, and create from the information they have acquired in their reading assignments. Through the flipped classroom, students are given the chance to prepare ahead and the teacher can plan the lesson with student capabilities in mind. Improving the performance of the students before class, that is, in a flipped classroom set-up, will likely improve their performance in an active learning activity in class like the peer instruction.

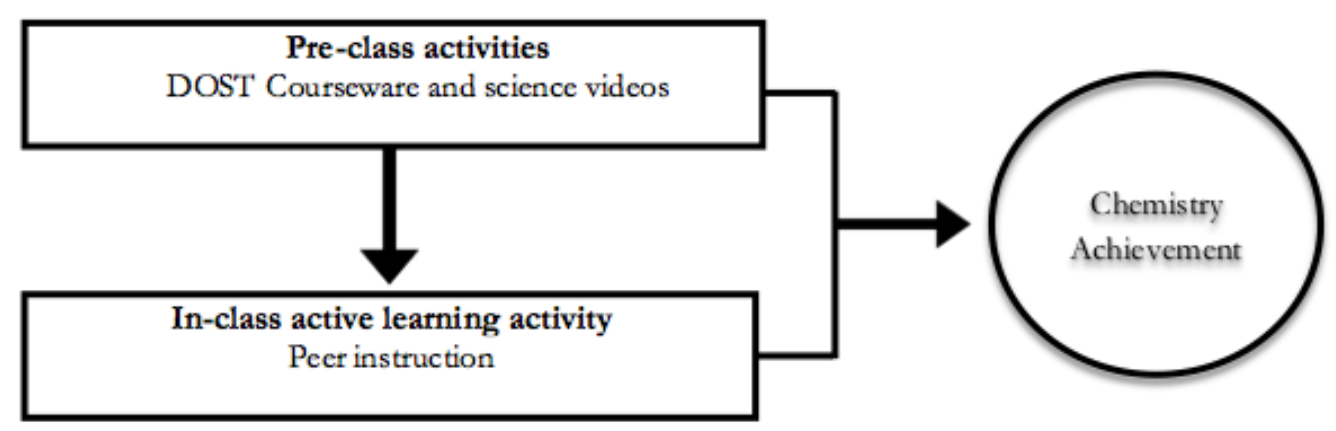

Figure 1. The conceptual framework

This study sought to answer the following questions:

1. Is there a significant difference in the Chemistry achievement of students exposed to the flipped classroom with peer instruction (FCPI) and traditional classroom with peer instruction (TCPI)? 
2. What is the level of student participation in the two classroom set-ups?

3. What are the perceptions of students on the two classroom set-ups?

\section{Methodology}

\subsection{Research design}

This study used a two-group quasi-experimental pretest-posttest control group research design (Rogers and Revesz, 2019) to compare Chemistry achievement among Grade 7 junior high school students exposed to FCPI (experimental group) and TCPI (control group). A 75-item Chemistry achievement pretest and post-test on the topics discussed during the implementation of the study was administered.

Table 1. The research design.

\begin{tabular}{llll}
\hline Intact Groups & Pretest & Treatments & Posttest \\
\hline Experimental & $\mathrm{O} 1$ & $\mathrm{FCPI}$ & $\mathrm{O} 2$ \\
\hline Control & $\mathrm{O} 3$ & $\mathrm{TCPI}$ & $\mathrm{O} 4$ \\
\hline
\end{tabular}

In addition, student participation and perception on peer instruction and flipped classroom method were examined through a survey. Students' journal entries were studied to validate and complement the quantitative findings of the study.

\subsection{Participants and content of the study}

The study was conducted in a public high school situated in a rural area in Sta.Cruz, Laguna, Philippines. Majority of the participants belonged to families with annual income below USD2004.91. Overall, 59 Grade 7 junior high school students (34 males and 25 females) were included in the TCPI and 49 students ( 28 males and 21 females) in the FCPI. The TCPI set-up had more students with "Satisfactory" Grade 6 science grades ranging from 80 to 84 , while the FCPI had more students with "Fairly Satisfactory" Grade 6 science grades ranging from 75-79. The number of participants in the FCPI was lower because a few days after the implementation of the study, six students in the FCPI set-up were dropped from the list because they either transferred to another school or incurred excessive absences. The equivalence of each group was established using two one-sided test (Lakens, 2017; Lewis and Lewis, 2005). Using independent samples $t$-test with equal variances, the equivalence test was significant 
( $p$-value $=0.00799$ ), given equivalence bounds of -2.611 and 2.611 (on a raw scale) and $\alpha=0.05$. Based on the equivalence test and the null-hypothesis test combined, the observed effect is statistically not different from zero and statistically equivalent to zero.

The implementation of the study was conducted for four (4) months in the first quarter of SY 2019-2020. The topics covered in the first quarter Grade 7 Department of Education science K-12 curriculum were components of a scientific investigation, properties of unsaturated or saturated solutions, concentrations of solutions, properties of mixtures and substances, elements and compounds, properties of acidic and basic mixtures, and metals and nonmetals.

\subsection{Treatments}

The FCPI teaching strategy was the intervention used in this study. The participants did not have exposure to flipped classroom and peer instruction prior to the conduct of the study. In the flipped classroom setting, the students were introduced to the lesson using the science courseware developed by DOST and from selected YouTube videos before class. Due to a lack of reliable internet connection at home, students access these materials offline using desktop computers and laptops available in the school. In class, the teacher focused on the discussion of concept questions which were answered using peer instruction and Plickers app.

For the control group, students were exposed to TCPI. The same content from the DOST science courseware and YouTube videos were discussed with the students. The lessons were enriched with various activities to cater to the different types of learners in the classroom. However, some activities were given as assignment in the TCPI due to limited class time. Both classrooms were taught by the same teacher and used PowerPoint presentation and LCD projector in delivering instructions in class. Daily lesson logs containing the scheduled laboratory demonstrations, activity sheets, board works, visual aids, recitations, and other activities served as a guide of the teacher in handling the classes. The activities for each group are described in Figure 2 and Figure 3.

Peer discussion was implemented as follows:

- Step 1: A question was posted by the teacher.

- Step 2: The students answered the questions individually. They raised their Plickers $^{\mathrm{TM}}$ card representing their answers. The teacher collected on-thespot student answers using a camera phone. Plickers is an assessment tool 
which allow quick assessment of student understanding of the lesson (Plickers, 2019).

- Step 3: When all students have given their answers, the teacher showed the percentage of students who got the correct answer.

- Step 4: The students were prompted to discuss their answers with their preferred partner.

- Step 5: After the peer discussion, the students were allowed to change their answer.

- Step 6: The teacher gave the correct answer and the explanation.

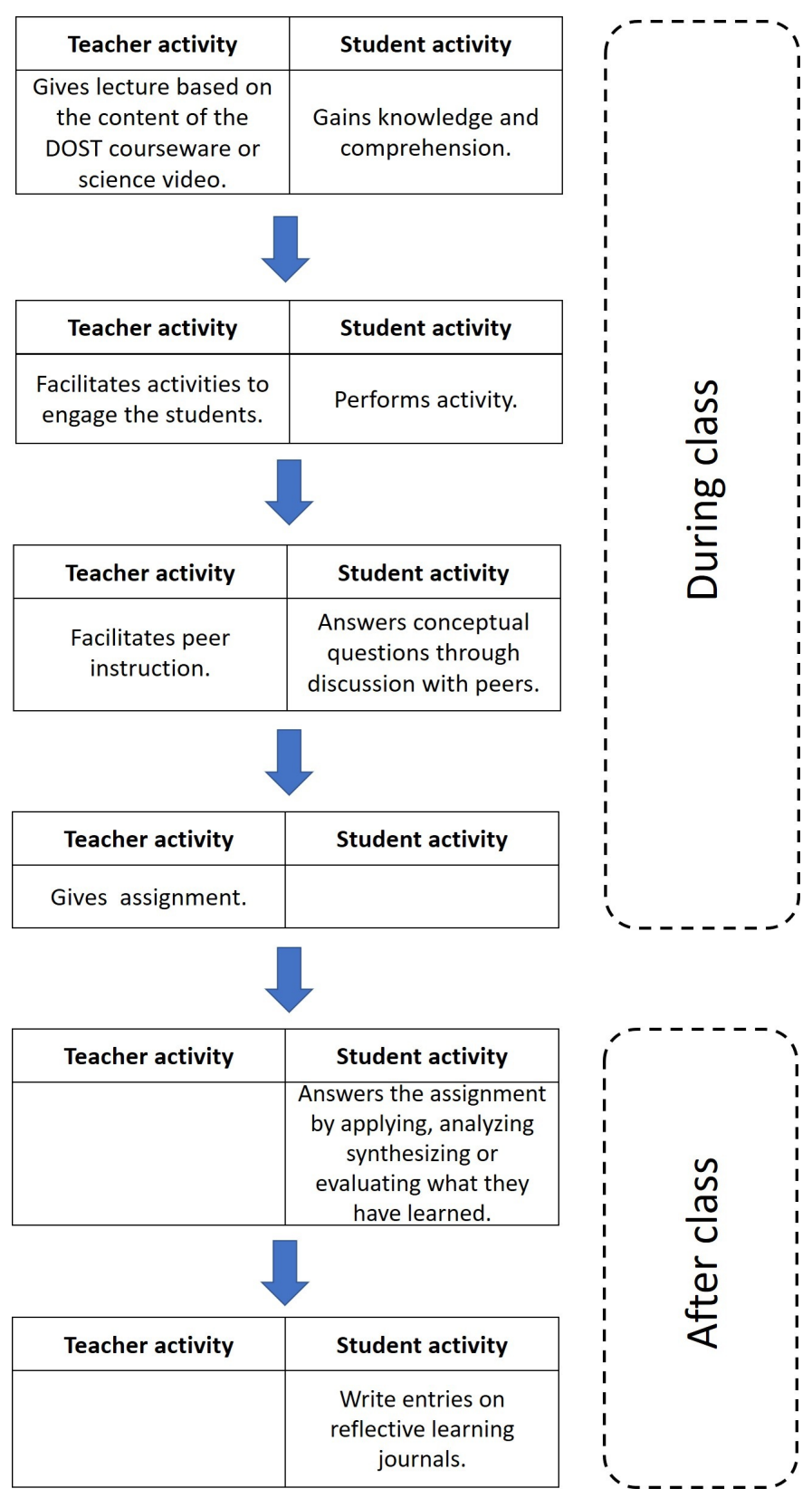

Figure 2. Flow of activities in TCPI. 


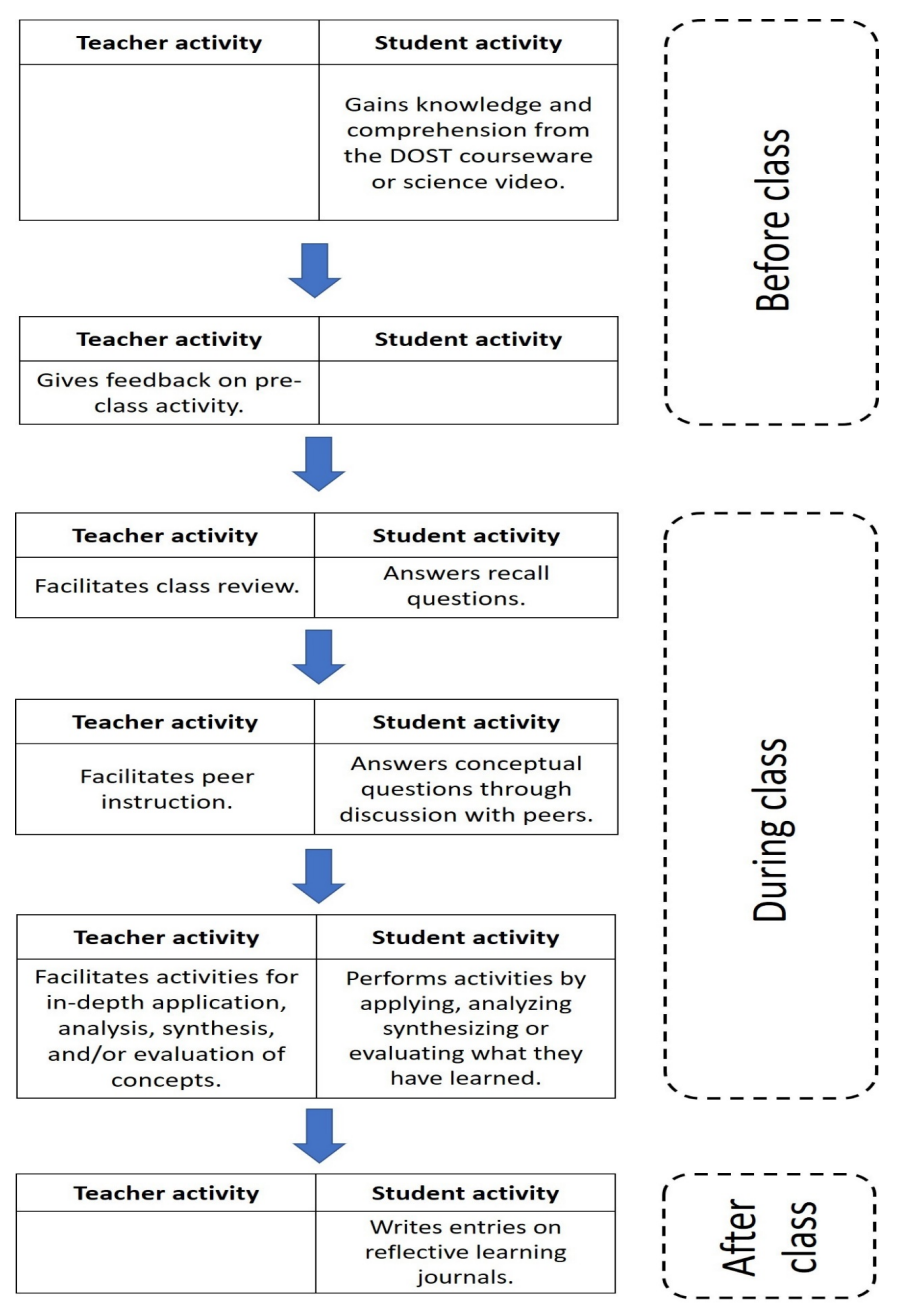

Figure 3. Flow of activities in FCPI.

\subsection{Instruments}

Chemistry achievement test

Participants in both groups took a 75-item multiple-choice type pre- and final tests in Chemistry covering topics on scientific investigation, solutions, concentration of solutions, substances, mixtures, elements, compounds, acids and bases, and metals and nonmetals. Validity evidence from test content was established by a panel of five science high school teachers, and pilot test to 111 Grade 8 junior high school students who have already taken the enumerated science competencies. Validity evidence based on internal structure was collected using exploratory factor analysis (Arjoon et al., 2013). The Kaiser-Meyer-Olkin (KMO) test was used to measure the sampling adequacy and determine if the data is suitable for factor analysis (Kaiser, 1974). According to Kaiser's guidelines, a suggested cutoff for determining the factorability of the sample data is $\mathrm{KMO} \geq 60$. The overall $\mathrm{KMO}$ is 0.74 , indicating that the data is 
suitable for factor analysis. The result of the KMO test is also supported by Bartlett's Test of Sphericity ( $p$-value $=3.213864 \mathrm{e}-12$ ). The parallel analysis suggests that the number of factors is 1 . The assumption of tau-equivalence as a requirement for Cronbach's alpha was met. The reliability coefficient of the achievement test was estimated at 0.708 using Cronbach alpha.

\section{Post-implementation surveys}

Survey questionnaires on student participation in class and perception of the treatments were given to the students at the end of the implementation (Centeno, 2016). Validity evidence from test content was established by a panel of five experienced high school teachers. Similar evidence based on internal structure was gathered for the post-implementation surveys. The overall KMO is 0.66 and 0.86 , respectively, indicating that the data is suitable for factor analysis. The result of the KMO test is also supported by Bartlett's Test of Sphericity ( $p$-value $=2.849352 \mathrm{e}-11$ and $p$-value $=1.635812 \mathrm{e}-86$, respectively). The parallel analyses of the postimplementation surveys do not satisfy tau-equivalence, thus, Omega Total $\left(\omega_{t}\right)$ coefficient for estimating reliability was used (McDonald, 1999). The Omega Total was computed to be 0.68 for the participation instrument and 0.91 for the perception instrument.

\subsection{Data Collection}

Data were collected from the scores of the students in the pre- and final tests for the quantitative research analysis. Survey questionnaires on the level of participation in class and perception of students were given after the implementation of the treatments. Students wrote their learning experiences, learning activities, and other related insights about the teaching strategy in a journal. Data collected from the learning journals were used in validating and interpreting the results of statistical analysis.

\subsection{Data Analysis}

All statistical analyses were set at a significance level of 0.05. Data collected from the scores of students in the pre- and final tests were analyzed using STATA-IC 12.1. For the hypothesis on the effect of TCPI and FCPI on Chemistry achievement of students, the assumptions of normality and homogeneity of variance were satisfied, thus, the 
parametric ANACOVA was used to test if there was a difference in the Chemistry achievement of students in the two classroom set-ups. The results were triangulated using journal entries. Data gathered from the post-implementation survey were analyzed using percentages.

\section{Results and Discussions}

\subsection{Chemistry Achievement of Students Exposed to the Classroom Set-} ups

Comparison of pretest and post-test scores within groups

Data gathered from the TCPI $(p$-value $=0.9892)$ and FCPI $(p$-value $=0.8545)$ satisfied the assumption of normality; thus, a parametric t-test was used. The tabulated results of the paired $t$-test showed sufficient evidence to say that the students in the TCPI and FCPI had an increase in Chemistry achievement as measured using the post-test after the treatment.

Table 2. Chemistry achievement of students in the TCPI and FCPI.

\begin{tabular}{llll}
\hline Treatments & $\begin{array}{l}\text { Paired t-test } \mathbf{p}- \\
\text { value }\end{array}$ & $\begin{array}{l}\text { Estimated } \\
\text { increase (\%) }\end{array}$ & $\begin{array}{l}\text { Standard } \\
\text { error } \\
\mathbf{( \% )}\end{array}$ \\
\hline $\mathrm{TCPI}$ & 0.0022 & 3.67 & 1.14 \\
\hline $\mathrm{FCPI}$ & 0.0016 & 4.99 & 1.46 \\
\hline
\end{tabular}

The use of the peer instruction resulted in an increase in the Chemistry achievement of the students. It is worth noting that the use of the flipped classroom contributed to an improved Chemistry achievement for students. This could be attributed to the difference in the level of student participation in each classroom and their perception of the science classroom they were in. As can be seen in succeeding discussions in the section Student Participation, the students in the FCPI were more engaged and motivated. Students recognized the value of the activities they did in their science class, and the rapport they had with their classmates and teacher. This indicates that students in the FCPI were seen to show good performance in a sustained manner. The flipped classroom environment greatly affected the performance and 
participation of students in class (Goss and Sonnemann, 2017). This was reflected in some of the journal entries (JE) of the students in the FCPI:

"I realized that learning is fun." - $J E 1$

"I learn to value the work of others." - JE2

"The things we need to do in science were not always easy...but I still finished them." - JE3

"Science is my favorite subject." - JE4

This study supports the findings of Unal and Unal (2017), which showed high student satisfaction with the flipped classroom model. The same experience was reported by the students who participated in the study of Shih and Tsai (2017) on students' perception of a flipped classroom in a marketing course. The students in Shih and Tsai's study also regarded the flipped classroom strategy to be engaging, interesting, and unique. The students already understood the lesson during class because they watched and studied the video before coming to class. The class hour became more interesting as the students learned by interacting with their classmates and teacher.

\section{Comparison of pretest and post-test scores between groups}

Data gathered from the pretest scores of the TCPI and the FCPI satisfied the assumption for normality and homogeneity of variance, thus t-test with equal variance was used for comparison. Results of the statistical analysis showed no sufficient evidence to say that the pretest scores of the students from the two classrooms differ $(p-$ value $=0.4155)$.

Table 3. Comparison of pretest and post-test scores of students in the TCPI and FCPI.

\begin{tabular}{cccccccc}
\hline Classroom set-up & $\mathbf{n}$ & \multicolumn{2}{c}{ Mean score } & \multicolumn{2}{c}{ Standard deviation } & \multicolumn{2}{c}{$\boldsymbol{p}$-value } \\
\hline & & Pretest & Posttest & Pretest & Posttest & Pretest & Posttest \\
\hline TCPI & 55 & 18.3 & 20.6 & 0.05 & 0.09 & & \\
\hline FCPI & 47 & 18.8 & 21.0 & 0.06 & 0.10 & & \\
\hline
\end{tabular}

Data gathered from the post-test scores of the students from the TCPI and FCPI failed to satisfy the assumption for normality, thus the nonparametric Mann-Whitney U test was used for comparison. Results of the statistical analysis showed no sufficient evidence to say that the post-test scores of the students from the two classrooms differ 
$(p-$ value $=0.4158)$. Further, using two one-sided test using Mann-Whitney Test, a $90 \%$ confidence interval is set at $[-2.000013,2.000032]$. Since the confidence interval is within the equivalence bounds of -4.945 and 4.945 (on a raw scale), thus, the equivalence test was significant. Based on the equivalence test and the nullhypothesis test combined, the observed effect is statistically not different from zero and statistically equivalent to zero.

Further statistical analysis using ANACOVA with Grade 6 science grade as covariate was conducted to compare the two classrooms in terms of Chemistry achievement. Before proceeding, the assumptions for ANACOVA were checked and satisfied: normal data ( $p$-value $=0.5575)$, homogeneity of variance ( $p$-value $=$ o.8952), equality of Grade 6 science grades of students in both groups ( $p$-value = 0.4461) and achievement in Chemistry are linearly dependent with Grade 6 science grade ( $p$-value < o.0001). Analysis using F-test $(p$-value $=0.5993)$ showed no sufficient evidence to say that there is a difference in the Chemistry achievement of students subjected to the two classroom set-ups. Though the FCPI is as good as the TCPI in its ability to increase the Chemistry achievement of the students, the students in the FCPI showed consistent good perception of the teaching strategy. They also showed improved behavior towards learning as reflected in their level of participation in class.

Sufficient evidence on the effectiveness of the FCPI over the TCPI may be gathered through a) longer exposure to the teaching strategy, b) allowing the students to bring home the pre-class activities for them to watch at a longer time or on a more frequent schedule, and c) taking into consideration other factors which can affect academic achievement like delivery of lesson, learning tools used, and teaching modality, among others.

\subsection{Student participation}

The two classroom set-ups were compared in terms of the level of student participation. The succeeding discussion highlighted the strengths and weaknesses of each classroom set-up in terms of resulting student participation. The summary of results is shown in Table 4 . 
Table 4. Level of participation of the students in the TCPI and FCPI set-ups.

Traditional Classroom with Peer Instruction ( $\mathbf{n}=55)$
Flipped Classroom with Peer Instruction $(n=47)$

Manner of Participation

\begin{tabular}{llllllll}
\hline Never & Seldom & $\begin{array}{l}\text { Some- } \\
\text { times }\end{array}$ & Always & Never & Seldom & $\begin{array}{l}\text { Some- } \\
\text { times }\end{array}$ & Always \\
\hline$\%$ & $\%$ & $\%$ & $\%$ & $\%$ & $\%$ & $\%$ & $\%$ \\
\hline
\end{tabular}

1. I attend classes regularly.

38.20

5.5

$56.4 \quad 29.8 \quad 0$

21.3

48.9

2. I complete assigned tasks on time.

38.20

34.5

$\begin{array}{lll}27.3 & 29.8 \quad 0\end{array}$

21.3

48.9

3. I contribute meaningfully in class discussion by answering 38.20 $\begin{array}{llll}50.9 & 10.9 & 29.8 & 0\end{array}$ 51.1 19.1 questions or asking relevant questions.

4. I attentively listen to the classroom $38.2 \quad 0$ 7.3 54.5 $29.8 \quad 0$

8.5 61.7 discussion.

5. I show no disruptive behaviour in class.

$45.5 \quad 0$ 20 34.5 38.3 4.3 19.1 38.3

6. I participate in class activities.

$38.2 \quad 1.8$

9.1

50.9

29.8

4.3

4.3

61.7

7. I show cooperative and supportive attitude during classroom discussion and $\begin{array}{lll}43.6 & 3.6 & 20\end{array}$ 32.7 29.8 4.3 8.5 57.4 activities.

8. I share my ideas in class and show respect for the $47.3 \quad 1.8$ 32.7 $\begin{array}{lll}18.2 & 29.8 \quad 0\end{array}$ 21.3 48.9 opinion of others.

\section{Attendance in class}

The results of the survey showed that more students in the TCPI (56.4 \%) attended class as compared to the FCPI (48.9\%). However, it was also evident that cutting classes and absenteeism is a problem in both classrooms. A portion of the students from the TCPI (38.2 \%) and FCPI (29.8\%) "never" attended class regularly. An informal interview with the students who were observed to cut classes revealed that 
some of the students helped their households by working as laborers in the construction of their homes in the afternoon, while some were sickly and lack financial resources to come back to school after eating lunch at home. Majority of the students were cutting classes to spend time with their schoolmates. These students were either repeaters or students who stopped schooling for a long time and then went back to school (balik-aral students). With their situation, it is possible that they got easily bored with the school activities thus decided to skip class.

Completion of assigned tasks. It is noticeable that more students in the TCPI 'never' completed assigned tasks on time (38.2 \%). On the other hand, in the FCPI, almost half of the students indicated that they 'always' completed assigned tasks on time (48.9\%). There was an observed big difference between the percentages of students that chose completing assigned tasks on time in the two-classrooms. As reflected in the journal entries of the students in the FCPI, they were eager to finish the assigned activities because they know that it will help them participate in class. In fact, they became worried when they were not able to finish the pre-class activities on time. They were anxious that their classmates will know more than them and that they will not be able to answer the recall questions during class.

Students in the TCPI perceived assignments differently. Assignments served as additional practice for the lesson discussed in class and were given to the students after a formal discussion of the topic was done in class. The assignments had minimal bearing on their performance in the next lesson. However, though this was not fully explored in this study, it is possible that some students just do not like assignments at all (Unal and Unal, 2017). This aspect requires further investigation.

Classroom discussion. Both classrooms have low percentages of students who always participate in classroom discussion by answering or asking relevant questions. Only $10.9 \%$ of the students in the TCPI 'always' participate in classroom discussion by answering or asking relevant questions. More students in the FCPI are always participating in classroom discussion (19.1\%). This shows that the design of the FCPI motivated students to participate and contribute meaningfully in classroom discussions. Their prior knowledge about the lesson allowed them to contribute meaningfully during the classroom discussion.

It is worth noting that although the students in the FCPI were already exposed to the learning materials, they still attentively listened to the classroom discussion $(61.7$ \%) compared with TCPI (54.5\%). Active listening was a specific indicator of student engagement in class as seen from the perspective of the teacher (Nyman, 2015). 
With regard to student behavior, more students in the TCPI showed disruptive behaviour in class (45.5 \%) than in the FCPI (38.3 \%). The disruptive behaviours reported in the journal entries were bullying, making noise, coming into class late, and cheating.

\section{Class/Group activities}

Majority of the students in the TCPI (50.9\%) and FCPI (61.7\%) always participated in-class activities. Hands-on, minds-on activities capture the student's interest especially in learning science. Some of the classroom activities done in class were crossword puzzles, role playing, matching types, demonstration of laboratory equipment, and taste tests for acids and bases. This was also in agreement with the characteristic study habits of the students who actively participate in group works and ask for help when they do not understand something in class.

Another criterion in which the two classroom set-ups differed greatly was the cooperative and supportive attitude in classroom discussion and activities. A larger percentage (43.6\%) of students in the TCPI 'never' showed cooperative and supportive attitude during class discussion and activities. Only a smaller percentage (32.7\%) showed 'always' cooperative and supportive attitude during class discussions and activities. On the other hand, cooperative and supportive attitude during classroom discussions and activities (57.4 \%) was observed in the FCPI. The students saw their classmates as instruments for their learning during group activities and peer instruction. They also saw the strengths, and weaknesses of their classmates through the different activities in class. According to Vygotsky in his social learning theory, important learning occurs when a student interacts and discusses with peers and/or tutors. Students interacting with competent peers effectively develop competencies and skills. Students learn from the explanation and approach of the more competent peer; in return, the more competent peer also learns as he applies the concept to different situations. This was captured by Porter et al. (2011) from the statements of his students who participated in flipped classroom with peer instruction saying that the bits of information thrown during peer instruction led them to the right answer, deeper understanding of the concepts and the different approaches to a problem.

As reflected in the result of the classroom observations in the FCPI, the students supported each other, and no atmosphere of competition was seen. This conducive classroom environment brought satisfaction to the students. Students in the FCPI wrote in their journal entries: 
"I am happy when me and my classmates show cooperative attitude during group activities." - JE5

"I learn many things during group activities." - JE6

"I learn from my classmates during group activities." - JE7

"Me and my partner helped each other to get the right answer." - JE8

The two classrooms differed by 30.7\% in students' sharing of ideas in class and showing respect for the opinion of others. More students in the TCPI (47.3 \%) 'never' shared ideas in class nor showed respect for the opinion of others. In the FCPI, 48.9 $\%$ of the students developed sharing of ideas in class and showed respect for the opinion of others. The first step to develop sharing ideas and showing respect for others in a classroom setting is to help students understand what is expected of them (Hannah, 2013). Once they have a clear idea of how the discussion will proceed, they will be more accountable of their actions. The constant presence of group activities in the FCPI seemed to train the students in sharing ideas and impressed on them the importance of respect for the opinion of others in order to accomplish a task. The peer instruction and group activities conducted in the TCPI could be too brief and not frequent enough to have an effect on student participation.

\subsection{Factors that prevent students from participating in class}

Based on the self-reported factors which prevented students from participating in class (Table 5), health problem was high in both the TCPI (29.1\%) and FCPI (31.9\%). This could be one of the reasons for frequent absences of students in class. The students in both TCPI (21.8 \%) and FCPI (31.9 \%) experienced personal/family problems which also prevented them from participating in class. 
Table 5. Factors that prevent students from participating in class.

\begin{tabular}{|c|c|c|c|c|}
\hline \multirow[t]{2}{*}{ Factors } & \multicolumn{2}{|c|}{$\begin{array}{l}\text { Traditional } \\
\text { classroom with } \\
\text { Peer Instruction } \\
\mathrm{n}=\mathbf{5 5}\end{array}$} & \multicolumn{2}{|c|}{$\begin{array}{l}\text { Flipped Classroom } \\
\text { with Peer Instruction } \\
n=47\end{array}$} \\
\hline & $*_{f}$ & $\%$ & $f$ & $\%$ \\
\hline 1. Health problems & 16 & 29.1 & 15 & 31.9 \\
\hline 2. Being not in good terms with peers & 15 & 27.3 & 16 & 34 \\
\hline 3. Laziness & 14 & 25.5 & 2 & 4.3 \\
\hline 4. Personal/Family problem & 12 & 21.8 & 15 & 31.9 \\
\hline $\begin{array}{l}\text { 5. Discussing things not related to science with my } \\
\text { peers }\end{array}$ & 5 & 9.1 & 6 & 12.8 \\
\hline 6. The physical environment (too hot or too cold) & 4 & 7.3 & 11 & 23.4 \\
\hline 7. Lack of resources and school supplies & 4 & 7.3 & 0 & 0 \\
\hline $\begin{array}{l}\text { 8. Being occupied with activities and requirements for } \\
\text { other subjects }\end{array}$ & 4 & 7.3 & 6 & 12.8 \\
\hline 9. Using gadget inside the classroom & 3 & 5.5 & 5 & 10.6 \\
\hline
\end{tabular}

*Frequency of students whose participation in class were affected by the given factors.

Being not in good terms with peers can also prevent students from participating in class, $27.3 \%$ in the TCPI and $34.0 \%$ in the FCPI. It was noticeable that this factor greatly affected the students in the FCPI. It was just logical because with the nature of the FCPI implemented in this study, being focused on group activities and peer instruction, it would be very difficult for a student to participate and perform in class if he is not in good terms with his classmates. Student-student relations play an important role in establishing a classroom environment. This relation can be seen whenever peers praise one another, smile at each other, and exchange personal stories and experiences (Barr, 2016). Aside from its effect in the classroom environment, positive student-student relation motivates students to learn and participate in class (Frisby \& Martin, 2010).

However, it was noteworthy that laziness ranked last in the factors that prevent students from participating in the FCPI (4.3\%), while it ranked third in the TCPI (25.5 
\%). This supported the succeeding discussions that the students in the FCPI were more engaged in class based on this survey. The students in the FCPI were more affected by the physical environment (23.4 \%). This should be a special consideration in implementing the FCPI. The classroom should be spacious and well ventilated to be conducive for conducting group activities that require extra movements among the students. This could also be applied to the computer laboratory, which they use during pre-class activities.

\subsection{Student perception of the classroom set-ups}

The post-implementation survey aimed to determine the perception of students on the implemented teaching strategies, including the materials used in class, the peer instruction (for the TCPI set-up), science videos and courseware (FCPI set-up), assignments and practice exercises, feedback from the instructor, and the technology used in class. The results of the survey are summarised in Table 6 for TCPI and Table 7 for the FCPI.

Table 6. Perception of students of the implemented TCPI set-up.

\begin{tabular}{llllllllllll}
\hline \multirow{2}{*}{ Criteria } & $\begin{array}{l}\text { Strongly } \\
\text { disagree }\end{array}$ & Disagree & $\begin{array}{l}\text { No } \\
\text { opinion }\end{array}$ & Agree & \multicolumn{2}{l}{$\begin{array}{l}\text { Strongly } \\
\text { agree }\end{array}$} \\
\cline { 2 - 11 } & ${ }_{f}$ & $\%$ & $*_{f}$ & $\%$ & $*_{f}$ & $\%$ & $*_{f}$ & $\%$ & $*_{f}$ & $\%$ \\
\hline $\begin{array}{l}\text { 1. The materials discussed in class helped } \\
\text { me understand the lesson. }\end{array}$ & 12 & 21.8 & 0 & 0 & 0 & 0 & 31 & 56.4 & 12 & 21.8 \\
\hline
\end{tabular}

2. The peer instruction using Plickers

allows me to communicate more with my $\quad \begin{array}{llllllllll}7 & 7.3 & 9 & 16.3 & 0 & 0 & 21 & 38.2 & 21 & 38.2\end{array}$ classmates.

3. The peer instruction using Plickers allows me to solve more problems in class.

$\begin{array}{llllllllll}0 & 0 & 5 & 9.1 & 2 & 3.6 & 28 & 50.9 & 20 & 36.4\end{array}$

\begin{tabular}{l}
$\begin{array}{l}\text { 4. I enjoy answering the } \\
\text { assignment and practice } \\
\text { exercises. }\end{array}$ \\
\hline
\end{tabular}

5. My teacher provided me feedback on my

$\begin{array}{llllllllll}11 & 20 & 5 & 9.1 & 5 & 9.1 & 27 & 49.1 & 7 & 12.7\end{array}$

assignments. 


\section{I was able to solve and analyse practice $\begin{array}{lllllllllll}\text { problems with my classmates during } & 5 & 9.1 & 0 & 0 & 4 & 7.3 & 35 & 63.6 & 11 & 20\end{array}$ class.}

7. The peer instruction using Plickers

$\begin{array}{lllllllllll}\text { allows me to monitor my progress } & 5 & 9.1 & 5 & 9.1 & 2 & 3.6 & 29 & 52.7 & 14 & 25.5\end{array}$
independently.

8. The peer instruction using Plickers

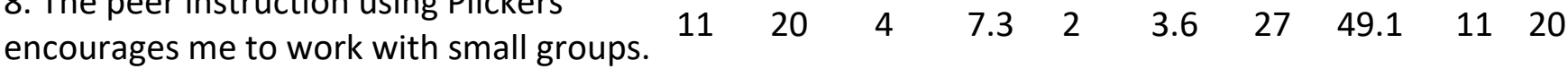

9. My instructor connects the assignments to the activities we had in class.

$\begin{array}{llllllllll}7 & 12.7 & 12 & 21.8 & 4 & 7.3 & 25 & 45.5 & 7 & 12.7\end{array}$

10. I easily adopted to the peer instruction and the technology used.

$\begin{array}{lllll}11 & 20 & 4 & 7.3 & 7\end{array}$

$\begin{array}{lllll}12.7 & 28 & 50.9 & 5 & 9.1\end{array}$

*Frequency of student responses describing their perception of the implemented TCPI.

Students in the TCPI agreed that the materials discussed in class helped them understand the lesson (56.4 \%). The use of an LCD projector and laptop saves time in displaying instructional materials in class. Also, the size of the visual can be easily adjusted and illustrations that are difficult to draw on the board can easily be displayed in the PowerPoint presentation.

Only $49.1 \%$ of the students in the TCPI agreed that the teacher provided them feedback on their assignments. The teacher was more focused on preparing for the next lesson rather than giving feedback on the previous lesson. In case feedback on an assignment is given, it is likely to be a little late because assignments were submitted after two days, and the feedback will be given the following science meeting. This was supported by the lower percentage ( $45.5 \%$ ) of students agreeing that the teacher was able to connect the assignments to the activities they had in class.

As a consequence, only $47.2 \%$ of the students agreed that they enjoyed their science assignments and practice exercises. Equal percentages of students in the TCPI agreed (38.2 \%) and strongly agreed (38.2 \%) that the peer instruction using Plickers allowed them to communicate more with their classmates. The students also agreed (50.9\%) that peer instruction allowed them to solve more problems in class. During peer instruction, the students were prompted to discuss their answers with their peers. This is consistent with the findings of Buchart et al. (2009) in his study of peer instruction in a philosophy class. This happens before showing the correct answer for 
an item. Though this communication lasted for less than a minute, their frequent communication with their peers in class removed their shyness and developed cooperation and participation.

In addition, the peer instruction using Plickers allowed the students to monitor their progress independently (52.7\%). Most of the students in the TCPI perceived that the implemented peer instruction helped promote problem-solving and analysis among classmates (63.6 \%). Students also agreed (49.1\%) that the peer instruction using Plickers encouraged them to work in small groups. Discussion among peers is a salient feature of peer instruction activity. This discussion is not limited to just telling the students' answer to the concept question. The students state why they chose that answer, why they think it is the correct answer, or why they think it should be changed.

Though peer instruction and the use of Plickers in class was something new to the students, $50.9 \%$ of the students easily adapted to the peer instruction and the technology used.

Table 7. Perception of students of the implemented FCPI set-up.

\begin{tabular}{llllllllllll}
\hline \multirow{2}{*}{ Criteria } & \multicolumn{2}{l}{$\begin{array}{l}\text { Strongly } \\
\text { disagree }\end{array}$} & Disagree & $\begin{array}{l}\text { No } \\
\text { opinion }\end{array}$ & Agree & Strongly agree \\
\cline { 2 - 9 } & $*_{f}$ & $\%$ & $*_{f}$ & $\%$ & $*_{f}$ & $\%$ & $*_{f}$ & $\%$ & $*_{f}$ & $\%$ \\
\hline
\end{tabular}

1. The instructional videos and science courseware I watch before the class help me understand the $\begin{array}{lllllllll}1 & 2.1 & 0 & 0 & 3 & 6.4 & 3 & 6.4 & 40\end{array}$ 85.1 lesson.

2. Watching instructional videos and science courseware prepares me to communicate more with my $\begin{array}{lllllllll}0 & 0 & 0 & 0 & 3 & 6.4 & 22 & 46.8 & 22\end{array}$ 46.8 classmates during class.

\section{Watching instructional videos} $\begin{array}{llllllllll}\text { and science course-ware allows me } & 0 & 0 & 0 & 0 & 0 & 0 & 6 & 12.8 & 41\end{array}$ to solve more problems in class.

\section{I enjoy answering the practice} exercises in the courseware and video at my own pace.

5. My instructor provided me $\begin{array}{lllllllllll}\text { feedback on my pre-class practice } & 0 & 0 & 0 & 0 & 0 & 0 & 10 & 21.3 & 37 & 78.7\end{array}$ problems. 
6. I was able to solve and analyse practice problems with my $\begin{array}{lllll}0 & 0 & 3 & 6.4 & 6\end{array}$ $12.7 \quad 25$

53.213

27.7 classmates during class.

7. Watching science videos and science courseware allows me to monitor my progress

$\begin{array}{lllllllll}0 & 0 & 3 & 6.4 & 0 & 0 & 4 & 8.5 & 40\end{array}$

85.1 independently.

8. Watching science videos and $\begin{array}{lllllllllll}\text { science courseware encourages me } & 0 & 0 & 0 & 0 & 1 & 2.1 & 3 & 6.4 & 43 & 91.5\end{array}$ to work with small groups.

9. My instructor connects the $\begin{array}{lllllllllll}\text { instructional videos and courseware } & 0 & 0 & 1 & 2.1 & 0 & 0 & 9 & 19.2 & 37 & 78.7\end{array}$ to the activities we had in class.

$\begin{array}{lllllllllll}\text { 10. I easily adopted to the flipped } & 1 & 2.1 & 1 & 2.1 & 1 & 2.1 & 10 & 21.3 & 34 & 72.3\end{array}$ classroom and the technology used.

*Frequency of student responses describing their perception of the implemented FCPI.

Though not all students were familiar with using computers, laptops, and tablets, 72.3\% easily adapted to the flipped classroom with peer instruction set-up and the technology used. In fact, their journal entries revealed that their limited exposure to such technologies influenced them to participate in the FCPI.

“The leveled up mode of learning made me more interested to learn." - JE9

"I don't have my own tablet. I was excited every time we use tablets in science."

$-J E 10$

The students in the FCPI 'strongly agreed' that the implemented strategy was helpful in making the students understand the lesson (85.1\%), allowing students to communicate more with classmates (46.8\%). They also enjoyed both the pre-class activities, and in-class activities (91.5\%). The majority of them strongly agreed that the FCPI allowed them to develop independent learning as they monitor their progress (85.1\%) and learn at their own pace (85.1\%). The students were given guide questions to be answered after watching the science courseware/video. This procedure helped students think about what they had learned (Miller, 2012). The place of the teacher was also recognised in giving feedback on pre-class assignments (78.7\%) and making connection between the pre- and in-class activities (78.7\%). The connection between the pre-class activity and the science lesson is an important consideration in implementing flipped classroom (Erhke, 2016). 
With the content delivered online in a flipped classroom, the students were divided into small groups and engaged in meaningful learning activities in class (Danker, 2015). There was also increased participation and time for feedback in the flipped classroom. Working in small groups also initiate participation and lessen intimidation among students. The flipped classroom also helped the students connect new and previous knowledge. Students are actively engaged physically and cognitively in a flipped classroom (Butt, 2014; Gaughan, 2014). Students who are actively engaged tend to perceive the content delivered to be more meaningful (Bormann, 2014). Students look forward to classroom activities and the things they will accomplish for the day.

An aspect of FCPI which needed improvement was the ability of the students to solve and analyse practice problems with their classmates. Only $27.7 \%$ of the students strongly agreed to this, while $53.2 \%$ agreed. To address this, some basic problem solving practice problems could be included in the pre-class activities.

The high level of agreement of the students in the FCPI on the criteria for evaluating the implemented strategy implied that the pre-class activities were found useful and were properly matched and connected to the in-class activities. The success of implemented FCPI was highly reliant on how the pre-class activity prepared the students for in-class activity. The pre-class activity in the implemented FCPI met the targets mentioned by Ehrke (2016): a) equip students with requisite content to follow in class lectures and activities, b) spark learner interest in the lesson, and c) encourage students to become effective note takers. The perception of students in the TCPI was seen to be two sided with the constant presence of students disagreeing on the given statements describing the aspects of the classroom. Also, the highest level of response of the students was at the 'agree' level only. The FCPI design was perceived well by the students compared to the TCPI.

\subsection{Student regard of the technology used in the flipped classroom}

Use of laptops and tablets to view the science courseware and videos. The students easily adopted to the use of laptops and tablets in learning science. They were engaged in watching the science courseware and videos. This became one of their favorite activities in class. They noted that the videos and courseware were educational and directly related to the science lessons. However, sometimes they cannot understand the content of the video because it was in English and when their classmates were noisy while viewing. Also, it was noteworthy that none in the FCPI reported that the 
pre-class activities were too much to study or too complicated. Several studies conducted on flipped classroom reported otherwise (Shih, 2017; Szparagowski, 2014).

Regarding the use of technology in class, the students in this study wrote the following in journal entries:

"The computer activities were exciting and fun." - JE11

"The science videos were easy to understand." - JE12

"I learn from the computer activities." - JE13

"I was amazed by the technology we used in science class." - JE14

"Using computer to learn science was my favorite, especially when I got the correct answer." - JE15

"I was able to complete my notes while viewing the science courseware and videos. - JE16

Use of Plickers app during peer instruction. Many students in the FCPI liked the use of Plickers card during peer instruction. They easily adapted to this technology. They also took advantage of the second chance feature of the implemented peer instruction to get the correct answer. In the process, the students developed the skill of choosing the correct answer. Later on during the implementation, students got $100 \%$ correct answer during the peer instruction. This motivated them to do more in class. They wrote in their journal entries:

"I enjoyed the science class because of the Plickers activity (used during peer instruction)." - JE17

"My thinking skills were developed during peer instruction." - JE18

"I accept it when I got the wrong answer, I just do my best in the second answer." - JE19

"My day is complete when we (the class) got $100 \%$ correct answer during Plickers (peer instruction) activity." - JE2O

\subsection{General evaluation of the science class}

After focusing on the individual teaching strategies, the students were asked to give a general evaluation of the science class. The answers of the students from the two classroom set-ups are summarised in Table 8. 
Table 8. General evaluation of the science class.

\begin{tabular}{|c|c|c|c|c|}
\hline & \multicolumn{2}{|c|}{$\begin{array}{l}\text { Traditional Classroom with Peer } \\
\text { Instruction }\end{array}$} & \multicolumn{2}{|c|}{$\begin{array}{l}\text { Flipped Classroom with Peer } \\
\text { Instruction }\end{array}$} \\
\hline & Responses & $\%$ & Responses & $\%$ \\
\hline \multirow{2}{*}{$\begin{array}{l}\text { Did you feel that you } \\
\text { had sufficient support } \\
\text { to learn during the } \\
\text { course? }\end{array}$} & Yes & 96.7 & Yes & 100.0 \\
\hline & No & 3.3 & No & 0.0 \\
\hline \multirow{2}{*}{$\begin{array}{l}\text { Were you given } \\
\text { sufficient opportunity } \\
\text { to practice concepts in } \\
\text { class? }\end{array}$} & Yes & 100.0 & Yes & 100.0 \\
\hline & No & 0.0 & No & 0.0 \\
\hline \multirow{6}{*}{ How? } & Assignment & 31.3 & Through quizzes & 53.8 \\
\hline & Seatwork & 25.0 & $\begin{array}{l}\text { Through the problems } \\
\text { solved during class }\end{array}$ & 38.5 \\
\hline & Quiz & 18.8 & During class review & 15.4 \\
\hline & Boardwork & 12.5 & & \\
\hline & $\begin{array}{l}\text { Peer instruction using } \\
\text { Plickers card }\end{array}$ & 12.5 & & \\
\hline & $\begin{array}{l}\text { Through the problems } \\
\text { solved during class }\end{array}$ & 12.5 & & \\
\hline \multirow{2}{*}{$\begin{array}{l}\text { Were you given } \\
\text { sufficient opportunity } \\
\text { to clarify concepts in } \\
\text { class? }\end{array}$} & Yes & 100.0 & Yes & 100.0 \\
\hline & No & 0.0 & No & 0.0 \\
\hline \multirow{2}{*}{ How? } & $\begin{array}{l}\text { The teacher explains } \\
\text { concepts which the } \\
\text { students do not } \\
\text { understand }\end{array}$ & 80.0 & $\begin{array}{l}\text { The teacher explains } \\
\text { concepts which the } \\
\text { students do not } \\
\text { understand }\end{array}$ & 100.0 \\
\hline & $\begin{array}{l}\text { The teacher explains as } \\
\text { she moves around to } \\
\text { check }\end{array}$ & 20.0 & & \\
\hline
\end{tabular}

The whole class of the FCPI felt they had sufficient support to learn during the course. The students were provided with well selected pre-class activities aligned with the in-class activities. The class was also enriched with group activities where the students can apply and reinforce what they have learned during the pre-class 
activities. In terms of opportunity to practice in class, both classrooms got $100 \%$ agreement among the students. The students in the TCPI practiced concepts through assignments (31.3\%) and seatwork (25.0 \%), quizzes (18.8 \%), board work (12.5\%), peer instruction (12.5\%), and problems solved during class (12.5\%). In the FCPI, the students identified quizzes (58.3\%), problems solved during class (38.5\%), and class review (15.4\%) as the activities where they practiced concepts. It was noticeable that the students in the FCPI can already apply concepts which they learned in the preclass activities during class review; thus, making the class time interactive. The students in the FCPI were equally equipped with knowledge which they applied in activities and discussion. On the other hand, the students in the TCPI applied concepts in their assignments. As previously discussed, there was less opportunity for such application of concept to be checked or reinforced by the teacher since the class proceeded to the next topic in the following science meeting. The pre-class activities in FCPI prepared the students before coming to class thus maximising the use of class time with high order activities as indicated in the framework of this study.

All the students in both classroom set-ups were given the opportunity to clarify concepts in class. However, in the TCPI, 80.0 \% of the students were able to clarify concepts which they did not understand through the teacher's explanation as she delivered the lesson, while the remaining $20.0 \%$ were able to clarify the concepts only when the teacher moved around to check their understanding. In this scenario, it is possible that the students were not able to resolve the questions when the teacher failed to move around. In the FCPI, all concepts were clarified during the class review. Since the class already performed a pre-class activity, the teacher can focus her discussion on concepts that were unclear to the students during the pre-class activity. In addition, since the students already had a background of the lesson, they were able to easily and immediately raise their questions for clarification during the class review.

Another interesting aspect of the implementation of the two teaching strategies were the activities listed by the students they did during science class. This enumerated activity gave a picture of student productivity and student engagement in the two set-ups. 
Table 9. Activities of the students during the science class.

\begin{tabular}{llll}
\hline Traditional Classroom with Peer Instruction & \multicolumn{3}{l}{ Flipped Classroom with Peer Instruction } \\
\hline Responses & $\%$ & Responses & $\%$ \\
\hline Writing notes & 66.7 & Peer instruction using Plickers card & 73.7 \\
\hline Listening to the teacher & 22.2 & Listening to the teacher & 57.9 \\
\hline Peer instruction using Plickers card & 18.5 & Studying & 26.3 \\
\hline Reading & 18.5 & Watching science courseware and videos & 31.6 \\
\hline Group activity & 3.7 & Group activity & 10.5 \\
\hline Playing around & 40.7 & Recitation & 10.5 \\
\hline Making noise & 29.6 & Quiz & 10.5 \\
\hline Using cellphone & 7.4 & Review & 5.3 \\
\hline Bullying & 3.7 & Journal writing & 5.3 \\
\hline & & Cooperating & 5.3 \\
\hline
\end{tabular}

The top 4 activities the students in the FCPI do during science class were peer instruction using Plickers card, listening to the teacher, and studying. The students in the FCPI maximised the benefit of the peer instruction because they were prepared before coming to class. This was validated by their responses in the open-ended questions that the pre-class activities support their learning because without it they cannot answer the questions in class. The student responses also mentioned that the flipped classroom strategy allowed them to do more activities in class, allowed them to know what will be discussed in class and that the contents of the science courseware and videos were reinforced in class. They attentively listened and followed the discussion of the teacher. This is an assurance that the role of the teacher in the flipped classroom was strengthened and not threatened.

Other academic-related activities included in their list were: group activity, recitation, quiz, class review, journal writing, cooperating, and copying of notes. The only non-academic activity listed by the students in the FCPI was making noise. The 
combination of flipped classroom and peer instruction truly made the use of class time productive and academically inclined.

On the other hand, the top 4 activities listed by the students in the TCPI were not so academically inclined: writing down notes, playing around, making noise, and listening to the teacher. Managing disruptive behaviours in class consumes much of the class time instead of the teacher teaching (Guardino and Fullerton, 2010). As a matter of fact, $30 \%$ of the learning time was lost because of disruptive behaviours in class (TALIS Executive Summary, 2009). Though an active learning activity was present in the TCPI, the class time was not maximised as it was too focused on delivering the content to the students. Due to time constraint, the application and practice of the content were commonly done as take home assignments. The students in the TCPI were not able to fully maximise the benefit of the peer instruction and only had limited participation because they only relied on the content to be delivered by the teacher during class.

\section{Conclusions}

The students in the TCPI and FCPI had an increase in Chemistry achievement as measured by their scores in the post-tests. The gain in learning of the students in the FCPI was evident and they showed observable classroom participation. However, further statistical analysis showed no sufficient evidence to say that these scores are significantly different.

The students in the FCPI showed observable classroom participation than the students in the TCPI. The design of the FCPI implemented in this study made students complete their assigned tasks on time, show cooperative and supportive attitude during classroom discussion and activities, share ideas in class, and show respect for the opinion of others. The students in the TCPI were not able to show evidence of these aspects of classroom participation. Similar level of participation and attitude was seen in the flipped classroom and traditional classroom groups in an English class in Malaysia (Muniandy, 2018).

Students highly accepted the strategies used in the FCPI. Majority of the class 'strongly agreed' that modality aided the students in understanding the lesson, communicating with classmates in class, solving problems, answering practice exercises at their own pace, receiving feedback on the pre-class practice problems, monitoring progress independently, working with small groups, providing connection between instructional videos and courseware and activities in class, and adapting to 
the flipped classroom and the technology used. The students in this group 'agreed' that the implemented FCPI allowed them to solve and analyse practice problems with their classmates in class. On the other hand, TCPI was accepted by the students as indicated by the number of students who 'agreed' on the criteria used in the study.

The findings of this study highlighted the importance of giving students prior exposure to the learning materials in science whenever appropriate. In this way, the students can prime themselves with the learning content and be prepared to apply or clarify the concept in class. The use of technology in teaching and learning was proven effective in engaging and enticing students to learn. As shown in this study, having limited exposure to digital material didn't hinder the students from adjusting to a certain teaching strategy, instead, it excites them more to learn using gadgets and technology.

Not all teachers are 'digital natives'. Many would be hesitant to try including technology in class. However, this study shows that the use of animations and technology-supported media was highly recommended for abstract Chemistry lessons.

Teachers should not be afraid aim for higher level of learning goals in class. The implemented FCPI approach provided students with sufficient support in terms of materials, technology, scaffolding, and social interactions in class which enabled them to be independent learners. When students are prepared, they know and believe that they can perform in class; and once a small goal is achieved, they will continue trying until they reach our standard.

\section{Acknowledgement}

This research was supported by the Department of Science and Technology - Science Education Institute (DOST-SEI) through the Capacity Building Program in Science and Mathematics Education and by granting permission to use the science courseware and providing hardware used in the study. 


\section{References}

Arjoon J. A., Xu X. and Lewis J. E., (2013), Understanding the state of the art for measurement in chemistry education research: examining the psychometric evidence, Journal of Chemical Educacation, 90(5), 536-545.

Baroody, A. J. (2003). The development of adaptive expertise and flexibility: The integration of conceptual and procedural knowledge. In A. J. Baroody and A. Dowker (Eds.) Studies in mathematical thinking and learning. The development of arithmetic concepts and skills: Constructing adaptive expertise. Lawrence Erbaum Associates Publisher.

Berk, L. and WInsler, A. (1995). Scaffolding children's learning: Vygotsky and early childhood education. NAEYC Research into Practice Series. Vol 7. ISBN-0-935989-68-4. URL http://eric.ed.gov/?id=ed384443

Bormann, J. (2014). Affordances of flipped learning and its effects on student engagement and achievement. University of Northern Iowa.

Bransford, J. D., Brown, A. L., and Cocking, R. R. (2000). How people learn: Brain, mind, experience, and school: Expanded Edition. (2nd). National Academies Press. https://doi.org/10.17226/9853

Buchart, S., Handfield, T., and Restall, G. (2009). Using peer instruction to teach philosophy, logic and critical thinking. Teaching Philosophy. 32(1), 1-40.

Butt, A. (2014). Student views on the use of a flipped classroom approach: Evidence from Australia. Business Education and Accreditation. 6(1): 33-43. Retrieved on April 14, 2016 from http://search.proquest.com/docview/1446438932?accountid=14691

Cagande, J.L.L. and Jugar, R.R. (2018). The flipped classroom and college Physics students' motivation and understanding of kinematics graphs. Issues in Educational Research. 28(2): 288-307.

Calamlam, J.M.M. (2016). Effectiveness of blended e-learning approach in a flipped classroom environment. Official conference proceeding. The Asian Conference on Society, Education and Technology.

Camiling, M.K. (2017). The flipped classroom: Teaching the basic science process skills to highperforming 2nd Grade students of Miriam College Lower School. IAFOR Journal of Education. 5: 213-230.

Centeno, E.G. and Sompong, N. (2016). Development of a blended learning system using the flipped classroom model to enhance students' learning achievement in a development communication course. Journal of Rangsit University - Teaching and Learning, 1O(2).

Chou, C., and Lin, P. (2015). Promoting discussion in peer instruction: Discussion partner assignment and accountability scoring mechanisms. British Journal of Educational Technology. 46(4): 839-847. http://dx.doi.org/10.1111/bjet.12178

Crouch, C. H., Watkins, J. Fagen, A. P., and Mazur, E. (2007). Peer instruction: engaging students one-on-one, all at once. Research-Based Reform of University Physics, 1(1).

Custodio, A. (2020). Blended learning is the new normal in Philippine education. The Manila Times.

Danker, B. (2015). Using flipped classroom approach to explore deep learning in large classrooms. The IAFOR Journal of Education, 3(1), 171-186.

Ehrke, J. (2016). Developing pre-class activities for the flipped classroom. Pearson education. Retrieved on December 2019 from pearsoned.com.

Gayeta, N. E. (2017). Flipped classroom as an alternative strategy for teaching stoichiometry. Asia Pacific Journal of Multidisciplinary Research, 5(4), 83-89.

Gaughan, J. E. (2014). The flipped classroom in world history. History Teacher, 47(2), 221-244. 
Gilboy M.B., Heinerichs S., and Pazzaglia G. (2014). Enhancing Student Engagement Using the Flipped Classroom. https://doi.org/10.1016/j.jneb.2014.08.008

Goodwin, B., and Miller, A. (2013). Evidence on flipped classrooms is still coming in. Educational Leadership, $70(6), 78-80$.

Goss, P., and Sonneman, J. (2017) Engaging students creating classrooms that improve learning. Grattan Institute Report No. 2017-01.

Guardino, C. A. and Fullerton, E. (2010). Changing behaviors by changing the classroom environment. TEACHING Exceptional Children, 42(6), 8-13.

Hannah, R. (2013). The effect of classroom environment on student learning. Honor Thesis Paper 2375. Western Michigan University.

Ifenthaler, D., Gibson, D. C. and Zheng, L. (2018). The Dynamics of Learning Engagement in Challenge-Based Online Learning. 2018 IEEE 18th International Conference on Advanced Learning Technologies (ICALT). 178-182, https://doi.org/10.1109/ICALT.2018.00049

Kaiser, H. F. (1974). An index of factorial simplicity. Psychometrika, 39(1), 31-36.

Lewis, S.E. \& Lewis, J.E. (2005). The Same or Not the Same: Equivalence as an Issue in Educational Research. Journal of Chemical Education, 82(9), 1408.

Lucas, A. (2009). Using peer instruction and I-clickers to enhance student participation in calculus. Primus: Problems, Resources, and Issues in Mathematics Undergraduate Studies, 19(3), 219-231. Retrieved on April 17, 2016 from http://search.proquest.com/docview/213432272? accountid=47253.

Malto, G.A.O., Dalida, C. S. and Lagunzad, C.G.B. (2018). Flipped Classroom Approach in Teaching Biology: Assessing Students' Academic Achievement and Attitude Towards Biology. 4th International Research Conference on Higher Education, KnE Social Sciences. https://doi.org/10.18502/kss.v3i6.2403

McDonald, R. (1999). Test Theory: a Unified Treatment. Mahwah, NJ: Lawrence Erlbaum Associates.

Miller, A. (2012). Five best practices for the flipped classroom. Edutopia, 24, 2-12.

Morice, J., Michinov, N., Delaval, M., Sideridou, A., and Ferrieres, V. (2015). Comparing the effectiveness of peer instruction to individual learning during a chromatography course. Journal of Computer Assisted Learning, 31(6), 722-733.

http://dx.doi.org/10.1111/jcal.12116

Muniandy, V. (2018). Effectiveness of flipped classroom on students' achievement and attitudes towards English language in secondary school. Journal of InnovativeTechnologies in Education, 2, 9-15.

Nyman, R. (2015) Indicators of student engagement: What teachers notice during introductory Algebra lessons. Int. J. for Math. Teaching and Learning. Retrieved November 2019 from https://www.researchgate.net/publication/280719102_Indicators_of_student_engagemen t_What_teachers_notice_during_introductory_algebra_lessons

Organisation for Economic Cooperation and Development. (2009). Creating Effective Teaching and Learning Environments: First Results from TALIS. OECD. https://www.oecd.org/ education/school/43023606.pdf

Piaget, J. (2008). Origin of Intelligence in the Child: Selected Works Vol. 3. Routledge. ISBN 113622159X, 9781136221590.pp.357.

Plickers (2019). Formative assessment has never been faster. https://get.plickers.com

Porter, L., Bailey-Lee, C., Simon, B., and Zingaro, D. (2011). Peer instruction: Do students really learn from peer discussion in computing? The 7 th Annual International Computing Education Research Workshop.

Rivero, V. (2013). A new model to reach all students all ways. Internet@Schools, 20(1), 14-16. 
Rogers, John \& Revesz, Andrea. (2019). Experimental and quasi-experimental designs. The Routledge Handbook of Research Methods in Applied Linguistics, (pp 133-143).

Segumpan, L.L.B. and Tan, D.A. (2018). Mathematics performance and anxiety of junior high school students in a flipped classroom. European Journal of Education Studies, 4(12), 133. https://doi.org/10.5281/zenodo.1325918

Shih, W. L., and Tsai, C. Y. (2017). Students' perception of a flipped classroom approach to facilitating online project-based learning in marketing research courses. Australian Journal of Educational Technology, 33(5), 32-49.

Srinivasan, S., Gibbons, R. E., Murphy, K. L. and Raker, J. (2018). Flipped classroom use in chemistry education: results from a survey of postsecondary faculty members. Chemistry Education Research and Practice, 19, 1307-1318.

Szparagowski, R. (2014). The effectiveness of the flipped classroom. Honors Projects, 127. Bowling Green State University. Retrieved from https://scholarworks.bgsu.edu/honorsprojects/127

Unal, Z., \& Unal, A. (2017). Comparison of student performance, student perception, and teacher satisfaction with traditional versus flipped classroom models. International Journal of Instruction, 10(4), 145-164. https://doi.org/10.12973/iji.2017.1049a

Vygotsky, L. S. (1978). Mind in society: The development of higher psychological processes. Cambridge, MA: Harvard University Press. 